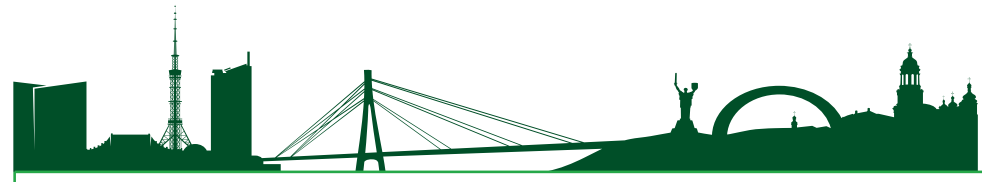

УДК 624.012.45/46.006.06

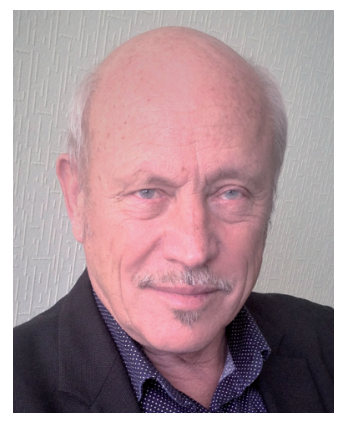

БАМБУРА А.M.

Д-р технічних наук, проф., ДП «Державний науководослідний інститут будівельних конструкцій», м. Київ, Україна e-mail: abambura@gmail.com тел.+38 (044) 249-37-44 ORCID: 0000-0003-1402-3345

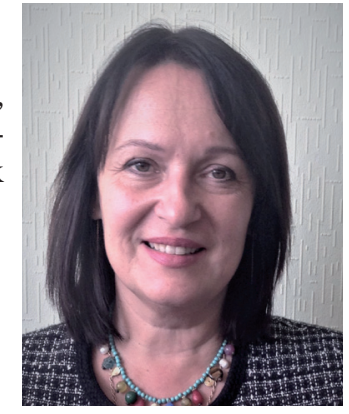

ДОРОГОВА О.В.

Канд. технічних наук, ст. науковий співробітник ДП «Державний науководослідний інститут будівельних конструкцій», м. Київ, Україна e-mail: dorogova@ukr.net тел. +38 (044) 249-37-75 ORCID: 0000-0002-7838-6383

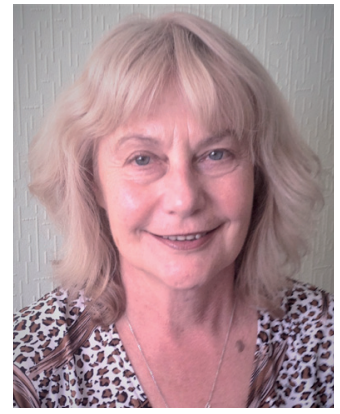

\title{
CAЗОНОВА I.P.
}

Інж., ст. науковий співробітник ДП «Державний науководослідний інститут будівельних конструкцій», м. Київ, Україна e-mail: rostislavovna@gmail.com тел. +38 (044) 249-38-88 ORCID:0000-0002-8226-3589

\section{ПОПЕРЕДНЕ ПРИЗНАЧЕННЯ ПАОЩІ РОЗТЯГНУТОЇ АРМАТУРИ ДАЯ КОНСТРУКЦІЙ ПРЯМОКУТНОГО ПЕРЕРІЗУ ПРИ ЗГИНІ}

\section{АНОТАЦІЯ}

Вступ. Згідно з вимогами державних будівельних норм України розрахунок залізобетонних конструкцій при дії згинального моменту та поздовжніх сил слід виконувати на основі розрахункової моделі нормального перерізу з використанням деформаційного методу. За критерій появи граничного стану, що розглядається, приймають досягнення деформаціями стиснутого бетону або розтягнутої арматури у перерізі ïх граничних значень або порушення рівноваги перерізу (екстремальний критерій). Але в практиці проектування часто виникає потреба нашвидкуруч оцінити несучу здатність конструкцій або визначити розрахунковим шляхом приблизне значення необхідної площі армування залізобетонних елементів. Тому, отримання залежностей для попереднього визначення площі армування для конструкцій прямокутного розрахункового перерізу при одношаровому армуванні в розтягнутій зоні є актуальним.

Мета. Метою даної роботи є розробка аналітичного апарату та методики розрахунку для попереднього визначення площі арматури в розтягнутій зоні прямокутного перерізу при одношаровому армуванні.

Розрахункові залежності. Запропоновано три спрощених підходи для попереднього визначення площі арматури в розтягнутій зоні при одношаровому армуванні елементів прямокутного перерізу. Перший підхід базується на реальній (криволінійній) діаграмі стану бетону. В другому підході використовується прямокутна епюра стиснутої зони бетону. Третій підхід дозволяє в першому наближенні отримати величину одного шару армування для конструкцій прямокутного перерізу незалежно від того, яка діаграма стану бетону використовується. В тому числі, і при необхідності визначення площі попередньо напруженої арматури.

Результати розрахунків. Виконано розрахунки раціонального армування балки за прямим деформаційним методом і за спрощеними залежностями. Виконано порівняння результатів спрощених підходів з "точним" рішенням.

Висновки. Представленний аналіз прямого підбору і трьох підходів до визначення площі арматури для конструкцій прямокутного перерізу з одним шаром армування показав, що всі вони дають практично один і той же результат. Похибка в попередньому визначенні площі арматури не перевищує 8,5\%. КАЮЧОВІ СЛОВА: залізобетонний елемент, деформаційний метод, прямокутний переріз, площа арматури, аналітичні залежності, попереднє напруження.

ПРЕДВАРИТЕАЬНОЕ

ОПРЕДЕЛЕНИЕ ПЛОЩАДИ РАСТЯНУТОЙ АРМАТУРЫ ДАЯ КОНСТРУКЦИЙ ПРЯМОУГОАЬНОГО СЕЧЕНИЯ ПРИ ИЗГИБЕ

БАМБУРА А.Н., д-р техн. наук, проф., ГП «Государственный научно-исследовательский институт строительных конструкций», г. Киев, Украина e-mail: abambura@gmail.com 


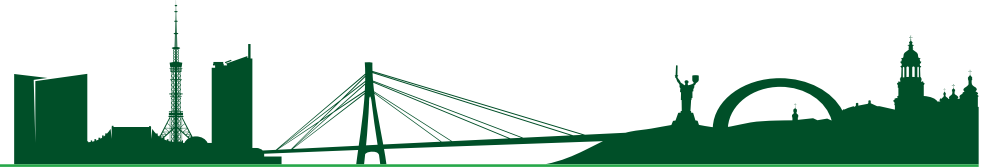

тел.+38 (044)249-37-44

ORCID: 0000-0003-1402-3345

ДОРОГОВА Е.В., канд. Техн. наук, ст. научный сотрудник ГП «Государственный научно-исследовательский институт строительных конструкций», г. Киев, Украина, e-mail: dorogova@ukr.net

тел. +38(044)249-37-75

ORCID: 0000-0002-7838-6383

САЗОНОВА И.Р., инж., ст. научный сотрудник ГП «Государственный научно-исследовательский институт строительных конструкций», г. Киев, Украина, e-mail: rostislavovna@gmail.com

тел. +38(044)249-38-88

ORCID:0000-0002-8226-3589

\section{АННОТАЦИЯ}

Введение. В строительных нормах Украины расчет железобетонных конструкций при действии изгибающего момента и продольных сил следует выполнять на основе расчетной модели нормального сечения с использованием деформационного метода. Критерием рассматриваемого предельного состояния принято достижение деформациями сжатого бетона или растянутой арматуры в сечении предельных значений относительных деформаций в соответствии с диаграммами их состояния. Но в практике проектирования иногда возникает потребность приблизительно оценить несущую способность конструкций или определить расчетным путем приблизительное значение необходимой площади армирования железобетонных элементов. Поэтому получение зависимостей для предварительного определения площади армирования для конструкций прямоугольного расчетного сечения при однослойном армировании в растянутой зоне является актуальным.

Цель. Целью данной работы является разработка аналитического аппарата для предварительного определения площади арматуры в растянутой зоне прямоугольного сечения при однослойном армировании.

Расчетные зависимости. Предложено три упрощенных подхода для предварительного определения площади арматуры в растянутой зоне при однослойном армировании элементов прямоугольного сечения. Первый подход базируется на криволинейной диаграмме состояния бетона. Во втором подходе используется двухлинейная диаграмма и прямоугольная эпюра сжатой зоны бетона. Третий подход позволяет в первом приближении получить величину площади армирования для конструкций прямоугольного сечения независимо от того, какая диаграмма состояния бетона используется. В том числе, и при необходимости начального определения площади предварительно напряженной арматуры.

Результаты расчетов. Выполнены расчеты "точного" рационального армирования балки деформационным методом и с использованием упрощенных подхо- дов. Проведено сравнение результатов упрощенных подходов с "точным" решением.

Выводы. Представленный анализ прямого подбора и трех подходов к определению площади арматуры для конструкций прямоугольного сечения с одним слоем армирования показал, что все они дают практически один и тот же результат. Погрешность в определении площади арматуры не превышает 8,5\%.

КАЮЧЕВЫЕ CגОВА: железобетонный элемент, деформационный метод, прямоугольное сечение, площадь арматуры, аналитические зависимости, предварительное напряжение.

\section{PRELIMINARY DETERMINATION OF THE TENSILE REINFORCEMENT AREA FOR STRUCTURES WITH RECTANGULAR SECTION IF BENDING}

BAMBURA A.M., Dr., Prof., State enterprise «The State Scientific Research Institute of Building Constructions», Kyiv, Ukraine

e-mail: abambura@gmail.com

tel. +38 (044)249-37-44

ORCID: 0000-0003-1402-3345

DOROGOVA O.V., PhD, senior scientist, State enterprise «The State Scientific Research Institute of Building Constructions», Kyiv, Ukraine,

e-mail: dorogova@ukr.net

tel. +38 (044)249-37-75

ORCID: 0000-0002-7838-6383

SAZONOVA I. $R$., Engineer, senior scientist, State enterprise «The State research Institute of Building Constructions», Kyiv, Ukraine

e-mail: rostislavovna@gmail.com

tel. +38 (044)249-38-88,

ORCID:0000-0002-8226-3589

\section{ABSTRACT}

Introduction. In Ukrainian construction codes, the calculation of reinforced concrete structures under the action of bending moment and longitudinal forces should be performed on the basis of a calculation model of normal section using the deformation method. Achievement by deformations of compressed concrete or tensile reinforcement of the limit values is the criterion for the limit state under consideration. The limit deformations are determining to meet the corresponding diagrams of concrete and reinforcement work. Despite the fact that the norms have been in operation for more than five years, designers have some difficulties in determining of the initial value of the required reinforcing concrete reinforcement area. In addition, there is sometimes a need to quickly assess the bearing capacity of structures. Therefore, the development of dependencies for the initial determination of the reinforcement area for structures with rectangular cross section with single- 


\section{WII 1 Malm}

layered reinforcement in a tensile zone is relevant.

Goal. The purpose of this work is to develop an analytical apparatus for the preliminary determination of the area of reinforcement in a tensile zone with singlelayer reinforcement.

Calculation dependencies. Three simplified approaches are proposed for the preliminary determination of the area of reinforcement in a tensile zone with single-layer reinforcement of elements of a rectangular section. The first approach is based on the curvilinear diagram of the concrete state. In the second approach, a two-line diagram and a rectangular diagram of a compressed concrete zone are used. The third approach allows in the first approximation to get the value of one layer of reinforcement for the structures with rectangular section, regardless of which diagram of the concrete will be used. Including, and if there is necessity in initial determination of the area of prestressed reinforcement.

Results of calculations. Calculations of the "exact" rational reinforcement of the beam according to the deformation method and the simplified dependencies are executed. A comparison of the results of simplified approaches with "exact" solutions has been performed.

Conclusions. The analysis of direct selection and three approaches to determining the area of the reinforcement for the structures with rectangular section with one layer of reinforcement has showed that they all give practically the same result. The error in the preliminary determination of the area of reinforcement does not exceed $8.5 \%$.

KEY WORDS: reinforced concrete element, deformation method, rectangular section, reinforcement area, analytical dependences, pre-stressing.

\section{ВСТУП}

Автори будівельних норм [1, 2] отримали багато зауважень і побажань стосовно відсутності в цих нормах рекомендацій щодо визначення спрощеним розрахунковим шляхом значення необхідної площі армування залізобетонних елементів. Тому розроблення простих залежностей для визначення площі армування для прямокутного розрахункового перерізу при одношаровому армуванні в розтягнутій зоні є актуальним. Найбільш точно можна визначити площу раціонального армування для різних форм розрахункового перерізу при довільній кількості шарів арматури і довільному поєднанні арматурних стрижнів різної природи і з різними властивостями (сталева, на основі скла, базальту, вуглецю, ненапружена і попередньо напружена) прямим підбором із використанням рівняння рівноваги за деформаційним методом $[3,4]$.

\section{META}

Метою даної роботи є розробка спрощеного аналітичного апарату для визначення площі арматури в розтягнутій зоні при одношаровому армуванні.

\section{РОЗРАХУНКОВІ ЗАЛЕЖНОСТI}

При згині елемента прямокутного перерізу з армуванням у розтягнутій зоні в один шар при забезпеченні вимог щодо конструювання, згідно з розділом 7 [1], можна виконати приблизне призначення армування. Приблизне тому, що рівняння рівноваги (4.3) та (4.4) [1] є системою нелінійних рівнянь і іï рішення в граничному стані не завжди відповідає максимальній несучій здатності, діаграма “момент-кривизна” в ряді випадків має екстремум (є низхідна гілка), який знаходиться далеко від граничного стану за деформаціями. Для розробки спрощеної методики визначення армування прямокутного перерізу за раціональний граничний стан приймають одночасну реалізацію граничних деформацій бетону в стиснутій зоні $\left(\varepsilon_{c u}\right)$ i деформацій розтягнутої арматури на межі текучості $\left(\varepsilon_{y 0}\right)$. Тому, для спрощеної методики визначення армування, у випадку, що розглядається, рекомендується використовувати наступні підходи.

Перший підхід. Розглянемо можливість отримання рішення щодо визначення раціональної площі арматури з рівнянь (4.3) та (4.4) [1], оскільки при згині в граничному стані реалізується друга форма рівноваги. Звертаємо увагу на те, що в будівельних нормах України прийнято таке правило знаків: для стиску як бетону, так і арматури знак додатний, для розтягу - від'ємний.

$$
\begin{gathered}
\frac{b f_{c d}}{\bar{\aleph}} \sum_{k=1}^{5} \frac{a_{k}}{k+1} \gamma^{k+1}+\sum_{i=1}^{n} \sigma_{s i} A_{s i}=0 \\
\frac{b f_{c d}}{\overline{\aleph^{2}}} \sum_{k=1}^{5} \frac{a_{k}}{k+2} \gamma^{k+2}+\sum_{i=1}^{n} \sigma_{s i} A_{s i}\left(x_{1}-z_{s i}\right)-M=0
\end{gathered}
$$

де:

b- ширина перерізу, м;

$f_{c d}$ - розрахункове значення міцності бетону на стиск, МПа;

$$
\aleph=\frac{1}{\rho}=\frac{\left(\varepsilon_{c(1)}-\varepsilon_{c(2)}\right)}{h}-\text { кривизна вигнутої осі в пе- }
$$

рерізі;

$\boldsymbol{\varepsilon}_{c(1)}-$ деформації бетону стиснутої фібри;

$\varepsilon_{c(2)}$ - осереднені деформації розтягнутої фібри бетону;

$$
\gamma=\frac{\varepsilon_{c(1)}}{\varepsilon_{c 1}}-\text { допоміжна величина; }
$$

$x_{1}=\varepsilon_{c(1)} / \aleph$

$\bar{\aleph}=\aleph / \varepsilon_{c 1}-$ відносна кривизна;

$A_{s i}$ - площа арматури в і-му шарі;

$\sigma_{s i}-$ напруження в арматурі і-го шару;

$z_{s i}$ - відстань і-го стрижня або прошарку арматури від найбільш стиснутої грані перерізу;

$a_{k}-$ коефіцієнти поліному, що описує нелінійну залежність між напруженнями та деформаціями бетону [4, Додаток Д].

Аналіз рівнянь рівноваги (1), (2) показав, що не складно визначити армування в граничному стані (рис. 1) за обома рівняннями. Для цього виконаємо 


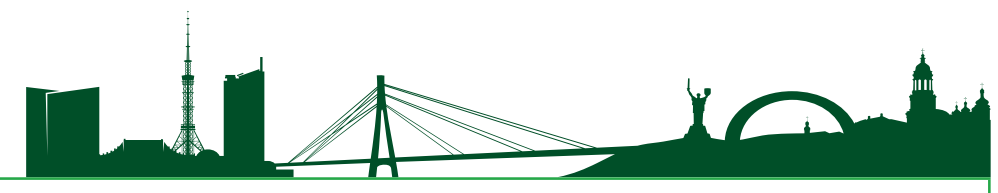

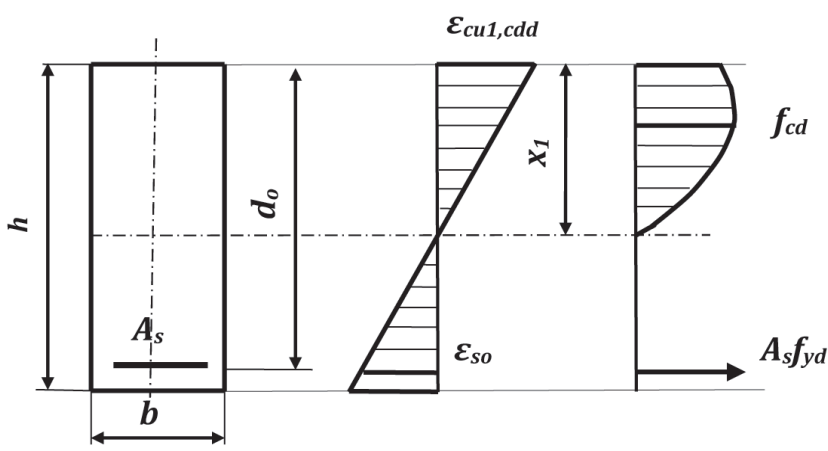

Рис.1. Напружено-деформований стан прямокутного перерізу в граничному стані

наступні перетворення зазначених рівнянь:

$$
\begin{gathered}
\frac{b f_{c d}}{\bar{\aleph}} F_{c N}+f_{y d} A_{s i}=0 ; \\
\frac{b f_{c d}}{\bar{\aleph}} F_{A M}+f_{y d} A_{s}\left(x_{1}-d_{0}\right)=M,
\end{gathered}
$$

де: $M-$ згинний момент;

$$
F_{c N}=\sum_{k=1}^{5} \frac{a_{k}}{k+1} \gamma_{c u}^{k+1}, F_{A M}=\sum_{k=1}^{5} \frac{a_{k}}{k+2} \gamma^{k+2} \gamma_{c u}^{k+2},
$$

де:

$$
\gamma_{c u}=\frac{\varepsilon_{c u 1}}{\varepsilon_{c 1}}, \aleph=\frac{\varepsilon_{c u 1}-\varepsilon_{s 0}}{d_{0}}, \bar{\aleph}=\frac{\varepsilon_{c u 1}-\varepsilon_{s 0}}{d_{0} \varepsilon_{c 1}} .
$$

При згині більш достовірні результати дає використання рівняння моментів (2), а рівняння (1) можна використати для перевірки рівноваги перерізу.

Таким чином, отримаємо:

де:

$$
A_{s}=\frac{M-\frac{b f_{c d}}{\overline{\bar{\aleph}^{2}}} F_{A M}}{f_{y d}\left(x_{1}-d_{0}\right)}
$$

$x_{1}=\frac{\varepsilon_{c u 1}}{\aleph}$

$f_{\text {yd }}$ розрахункове значення міцності арматури на межі текучості;

\begin{tabular}{|c|c|c|c|c|c|}
\hline $\begin{array}{c}\text { Клас } \\
\text { бетону }\end{array}$ & $\begin{array}{c}\text { Розрахункове } \\
\text { значення } \\
\text { міцності бетону } \\
\text { на стиск } \mathrm{f}_{\text {cd }} \text {, } \\
\text { МПа }\end{array}$ & $\begin{array}{c}\text { Відносні } \\
\text { деформації стиску } \\
\text { бетону при } \\
\text { максимальних } \\
\text { напруженнях, } \\
\varepsilon_{\mathrm{cl}, \mathrm{cd}} \\
\end{array}$ & $\begin{array}{c}\text { Відносні } \\
\text { граничні } \\
\text { деформації } \\
\text { стиску бетону, } \\
\varepsilon_{\text {cul,cd }}\end{array}$ & $\begin{array}{c}\text { Проміжна } \\
\text { характери- } \\
\text { стика до (3), } \\
\text { F } \mathrm{cN}\end{array}$ & $\begin{array}{c}\text { Проміжна } \\
\text { характери- } \\
\text { стика до (4), } \\
\text { F }_{\text {см }}\end{array}$ \\
\hline $\mathrm{C} 12 / 15$ & 8,5 & 0,00158 & 0,00370 & 1,804354 & 2,07981 \\
\hline C16/20 & 11,5 & 0,00162 & 0,00359 & 1,776175 & 2,057379 \\
\hline $\mathrm{C} 20 / 25$ & 14,5 & 0,00165 & 0,00344 & 1,66341 & 1,844255 \\
\hline $\mathrm{C} 25 / 30$ & 17 & 0,00169 & 0,00328 & 1,54804 & 1,629363 \\
\hline C30/35 & 19,5 & 0,00172 & 0,00310 & 1,432574 & 1,427146 \\
\hline C32/40 & 22 & 0,00176 & 0,00293 & 1,313164 & 1,231755 \\
\hline C35/45 & 25 & 0,00180 & 0,00272 & 1,144587 & 0,980873 \\
\hline $\mathrm{C} 40 / 45$ & 27,5 & 0,00184 & 0,00257 & 1,054349 & 0,866816 \\
\hline $\mathrm{C} 45 / 55$ & 30 & 0,00187 & 0,00243 & 0,953721 & 0,744184 \\
\hline C50/60 & 33 & 0,00191 & 0,00229 & 0,84888 & 0,623162 \\
\hline
\end{tabular}

$d_{0}$ - робоча висота поперечного перерізу.

Для рішення зазначених рівнянь у граничному ста-

Таблиия 1. Розрахункові параметри для спрощеного визначення площі арматури ні необхідно мати значення величин $F_{c N}$ та $F_{c M}$. Вказані величини є константами для кожного класу бетону і можуть бути зведені в таблицю. Значення величин $F_{c N}$ та $F_{c M}$, для різних класів бетону представлені в таблиці 1.

Перевірку визначеної величини площі армування можливо виконати з залежності рівноваги сил, що діють у перерізі (2). При підстановці вихідних даних і отриманої величини площі армування, в ідеалі, ми маємо отримати суму, рівну нулю. Через причини, що зазначені вище, ми отримуємо деяку різницю двох членів рівняння (1). Якщо ця різниця не перевищує $5 \%$, то можна вважати, що площа армування визначена 3 достатньою точністю. При цьому, якщо перший член рівняння $\left(\frac{b f_{c d}}{\bar{\aleph}} F_{c N}\right)$, який є зусиллям стиснутого бетону, буде менший за другий член $\left(f_{y d} A_{s i}\right)$, який є зусиллям розтягнутої арматури, то це означає, що необхідно збільшити міцність бетону або виконати армування стиснутої зони. Якщо збільшення міцності бетону не призведе до необхідного результату, то при визначенні площі розтягнутої арматури необхідно враховувати арматуру стиснутої зони. Така арматура майже завжди повинна встановлюватись 3 конструктивних міркувань і може прийматись як розрахункова. В такому випадку, залежність (5) набуває вигляду:

де:

$$
A_{s 2}=\frac{M-\frac{b f_{c d}}{\aleph^{2}} F_{A M}-f_{y d 1} \cdot\left(\mathrm{x}_{1}-z_{\mathrm{s} 1}\right)}{f_{y d 2}\left(x_{1}-d_{0}\right)},
$$

$A_{s 1} \cdot A_{s 2}$ - площа стиснутої і розтягнутої арматури відповідно;

$f_{y d l}, f_{y d 2}$ - розрахункове значення міцності стиснутої і розтягнутої арматури на границі текучості відповідно;

$z_{s l}$ - відстань стиснутої арматури від найбільш стиснутої грані перерізу.

Другий підхід. Розглянуто можливість отримання відповідних залежностей для визначення раціонального армування при згині з аналізу напруженодеформованого стану (рис. 2) з використанням прямокутної епюри (діаграми «жорстко-пластичного» матеріалу) стиснутої зони (розділ 3.1.6, рис. 3.3 [4]). При цьому, немає необхідності використовувати граничний деформований стан перерізу. Складемо систему рівнянь рівноваги перерізу:

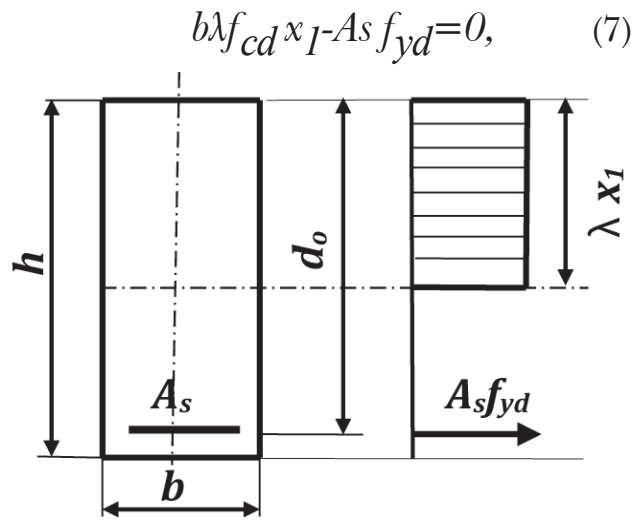

Рис.2. Напружено-деформований стан перерізу з використанням прямокутної епюри стиснутої зони 
де:

$$
-\lambda x_{1}^{2}+2 d_{0} x_{1}-2 \frac{M_{E d}}{b \lambda f_{c d}}=0,
$$

$\lambda=0,8$ - коефіцієнт, що уточнює розрахункову висоту стиснутої зони бетону;

$M_{E d}$ - розрахункове значення зовнішнього згинального моменту

Із залежності (6) отримуємо рівняння для визначення площі армування в розтягнутій зоні при відомому значенні висоти стиснутої зони $x_{l}$ :

$$
A_{s}=\frac{x_{1} b \lambda f_{c d}}{f_{y d}}
$$

Величину стиснутої зони $x_{1}$ можна визначити 3 рішення залежності (8), що представлена як квадратне рівняння. Тому, перш за все, визначимо величину дискримінанту квадратного рівняння:

$$
D=4 d_{0}^{2}-\frac{8 M_{E d}}{b f_{c d}},
$$

відповідно отримуємо

$$
x_{1}=\frac{-2 d_{0} \pm \sqrt{D}}{-2 \lambda} .
$$

Значення висоти стиснутої зони $x_{1}$ повинно бути позитивним і меншим розрахункової висоти перері3y $\left(d_{0}\right)$.

третій підхід. Деформаційний метод дозволяє в першому наближенні, виходячи з граничного деформованого стану (рис. 3), отримати величину одного шару армування прямокутного перерізу незалежно від того, яка діаграма стану бетону використовується.

Аналіз формули (5) показав, що другий член чисельника цієї залежності є моментом стиснутої зони відносно нейтральної осі перерізу. Відомо, що при рішенні системи рівнянь рівноваги відносно нейтральної осі, момент стиснутої зони чисельно рівний моменту розтягнутої арматури. Таким чином, момент розтягнутої арматури відносно нейтральної осі складає половину зовнішнього моменту, тому в першому наближенні залежність для визначення площі розтягнутої арматури має вигляд:

$$
A_{s}=\frac{-M}{2 f_{y d}\left(x_{1}-d_{0}\right)} .
$$

Для отримання площі арматури за залежністю (12), необхідно мати висоту стиснутої зони $x_{1}$. Висоту стиснутої зони визначають з розгляду граничного деформованого стану перерізу за залежністю:

$$
x_{1}=\frac{d_{0} \varepsilon_{c u 1, c d}}{\left(\varepsilon_{c u 1, c d}+\varepsilon_{s 0, d}\right)} .
$$

Аналогічно, як і в першому підході, аналізуємо необхідність зміни міцності бетону або встановлення арматури в стиснутій зоні. Для визначення раціональної площі розтягнутої арматури, необхідна перевірка величини висоти стиснутої зони $x_{1} \leq 0.6 d_{0}$. Якщо висота стиснутої зони значно більше $0.6 d_{0}$, необхідно збільшити клас бетону або встановлення арматури в стис- нутій зоні. Якщо збільшення класу бетону не призводить до потрібного результату, необхідно призначити розрахункову стиснуту арматуру. В цьому випадку площа розтягнутої арматури визначається за залежністю:

$$
A_{s 2}=\frac{-M+A_{s 1} \cdot f_{y d 1} \cdot\left(\mathrm{x}_{1}-z_{\mathrm{s} 1}\right)}{2 f_{y d 2}\left(x_{1}-d_{0}\right)},
$$

де:

$A_{s 1} A_{s 2}$ - площа стиснутої і розтягнутої арматури відповідно;

$f_{y d l}, f_{y d 2}$ - розрахункове значення міцності стиснутої і розтягнутої арматури на границі текучості відповідно;

$z_{s l}$ - відстань стиснутої арматури від найбільш стиснутої грані перерізу.

Залежності (12) та (13) можуть бути використані і при необхідності приблизного визначення площі попередньо напруженої арматури. В даному випадку, ми за граничний стан приймаємо досягнення граничних деформацій стиснутим бетоном (рис. 3), а деформації арматури при цьому

де:

$$
\Delta \varepsilon_{s p}=\varepsilon_{p 0}-\varepsilon_{s 0 s p}
$$

$\varepsilon_{p 0}$ - значення відносних деформацій видовження попередньо напруженої арматури;

$\varepsilon_{s 0 s p}$ - початкові деформації видовження попередньо напруженої арматури.

Приблизного тому, що при визначенні граничного стану не враховано роботу попередньо напруже-

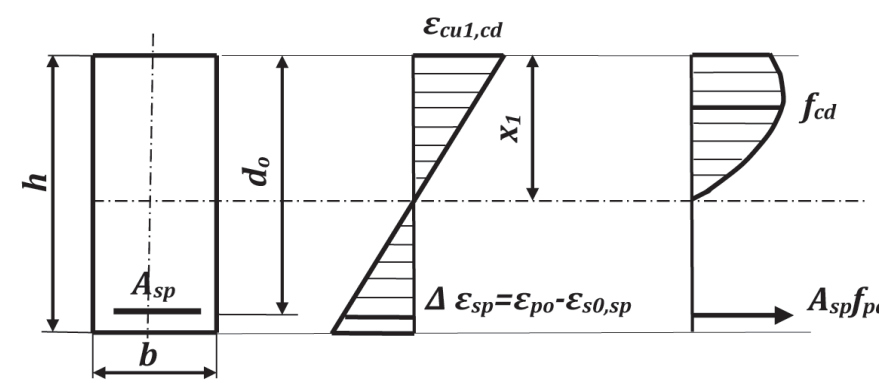

Рис.3. Напружено - деформований стан прямокутного перерізу з попередньо напруженою арматурою.

ної арматури на другій ділянці діаграми при $\varepsilon_{s p}>\varepsilon_{p 0}$. Тому, отримане значення розрахункової площі арматури буде декілька більше за необхідне для забезпечення достатньої несучої здатності розрахункового перерізу. Але при наступному перевірянні прямим розрахунком не важко буде уточнити та підібрати більш раціональне значення площі попередньо напруженої арматури при забезпеченні вимог за другою групою граничних станів.

Для розрахунку площі попередньо напруженої арматури використовують залежність (12). При цьому висоту стиснутої зони визначають за залежністю:

$$
x_{1}=\frac{d_{0} \varepsilon_{c u 1, c d}}{\left(\varepsilon_{c u 1, c d}+\Delta \varepsilon_{s p}\right)} \text {, }
$$

де : $\quad \Delta \varepsilon_{s p}=\varepsilon_{p 0^{-}} \varepsilon_{s 0 s p}$.

Для розрахунків реальних конструкцій бажано 


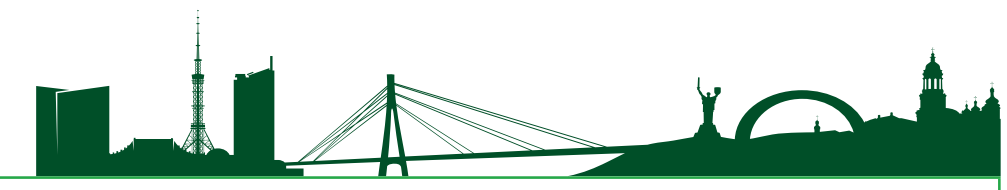

щоб величина $\Delta \varepsilon_{s p}=\varepsilon_{p 0^{-}} \varepsilon_{s 0 s p}$ не перевищувала значення 0,00210 для стрижнів діаметром менше 25 мм. При цьому, необхідно виконати перевірку відповідності вимогам за другою групою граничних станів. Так, ширину розкриття тріщин при $\Delta \varepsilon_{s p}>0,00210$ необхідно визначати розрахунком, i, як правило, вона буде перевищувати допустиму. Величину різниці деформацій $\Delta \varepsilon_{s p}$ можливо регулювати рівнем попереднього напруження або шляхом зменшення його втрат.

Авторами отримано аналогічні залежності для визначення площі одиночного шару арматури для прямокутного перерізу при використанні дволінійної діаграми деформування бетону. Оскільки, підрахунки за цими залежностями вимагають затрати значно більшого часу, вони не представлені. Тим більше, що найпростіші залежності (12) - (15) дозволяють визначити площу армування незалежно від того, яку діаграму деформування бетону використовують.

Пропонуємо такий алгоритм для попереднього визначення площі розтягнутої арматури для прямокутного перерізу.

1 Як вихідні дані - величини зовнішнього моменту $\left(M_{E d}\right)$, геометрії перерізу, захисного шару, кла-

2 Визначаємо параметри: $f_{c d}, \varepsilon_{c u l, d}, \varepsilon_{c l}, f_{y d}, \varepsilon_{s 0}=\frac{f_{y d}}{E_{s}}$ $d_{0}=h-c_{\text {по }}$ та $x_{1}$ за залежностями (13) або (15).

3 Перевіряємо величину висоти стиснутої зони $x_{l}$ $\leq 0.6 d_{0}$. Якщо висота стиснутої зони значно більша за $0.6 d_{0}$, необхідно збільшити клас бетону і виконати пп 1, 2. Якщо збільшення класу бетону не призводить до потрібного результату, необхідно призначити розрахункову стиснуту арматуру. В цьому випадку площа розтягнутої арматури визначається за залежністю (14).

4 Визначаємо необхідну площу арматури за залежністю (12) або (14).

5 Визначаємо кількість стрижнів, 3 дотриманням вимог щодо конструювання розділу 7 [1]. Відповідно коригуємо відстань від центру шарів стрижнів до найбільш стиснутої грані $\left(z_{s i}, d_{0}\right)$.

6 Виконуємо прямий розрахунок за системою рівнянь для другої форми рівноваги (4.3) та (4.4) [1].

7 Виконуємо співставлення несучої здатності із зовнішнім моментом $\left(M_{E d}\right)$. У випадку, коли несуча здатність $M_{u}$ менша за $M_{E d}$, необхідно збільшити площу армування. У випадку, коли несуча здатність більша за $M_{E d}$, необхідно виконати оцінювання точності рішення. Якщо це перевищення є меншим ніж 5\%, можна вважати, що необхідна точність рішення досягнута. На цьому розрахунки закінчено.

\section{РЕЗУАЬТАТИ РОЗРАХУНКІВ}

Ефективність визначення попереднього значення площі розтягнутої арматури покажемо на прикладі балки перекриття прямокутного перерізу. Необхідно визначити армування залізобетонної балки перекриття для заданого навантаження. Дано: залізобетонна балка перекриття довжиною 9 м $з$ розміра-

ми перерізу: $b=300 \mathrm{мм}, h=600 \mathrm{Mм}$; клас міцності бетону $\mathrm{C} 25 / 30\left(f_{c d}=17 \mathrm{M \Pi а} ; \varepsilon_{c u l, c d}=0,00328 ; \varepsilon_{c l, c d}=0,00169\right)$; клас арматури A500C (Es=200000 МПа, $f_{y d}=416,6$ МПа). Розрахункове навантаження 50 кН/м, граничний розрахунковий момент $M_{E d}=506$ кН·м.

Раціональним армуванням для залізобетонних елементів, що згинаються, є розміщення арматури в розтягнутій зоні залежно від міцності бетону від 2\% до 3\% площі перерізу. Тому, на першому кроці пошуку раціонального армування, можна прийняти вміст розтягнутої арматури балки приблизно 2\%, або $\mathrm{b} \cdot \mathrm{h} \cdot 0,02=0,3 \cdot 0,6 \cdot 0,02=0,0036 \mathrm{~m}^{2}$. Виходячи 3 цього, на першому кроці підбору арматури, призначаємо армування в розтягнутій зоні 3Ø32+2Ø28 А500С, верхнє армування конструктивне $2 \varnothing 12$ А500С. Захисний шар згідно рекомендацій розділу 4.2 [4], для першого шару арматури $32+10=42$ мм, для другого шару $42+32+35=109$ мм, для верхньої арматури -- 29 мм.

Виконуємо розрахунки несучої здатності балки за деформаційним методом. Використовуючи критерії вичерпання несучої здатності перерізу, отримуємо $M_{u}=545$ кН·м. Таким чином, визначена несуча здатність балки

$M_{u}=545 \kappa \mathrm{H} \cdot \mathrm{m}$ перевищує зовнішній момент

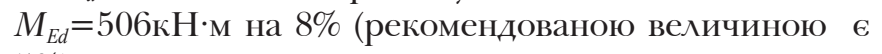
$5 \%)$.

Тому, виконуємо другий крок пошуку раціонального армування, приймаючи декілька зменшену площу арматури. Для першого шару в розтягнутій зоні назначаємо 3Ø25 А500С, для другого шару 3Ø25 А500С, верхне армування (в стиснутій зоні) конструктивне 2Ø12 A500С (рис. 4 та табл.2). Захисний шар для першого шару арматури 25+10=35 мм, для другого шару

Таблиия 2. Вихідні дані для розрахунку балки

\begin{tabular}{|c|c|c|}
\hline $\begin{array}{c}\text { Номери } \\
\text { шарів } \\
\text { арматури }\end{array}$ & $\begin{array}{c}\text { Площа } \\
\text { арматури } \\
\text { кожного } \\
\text { шару } \\
\mathrm{A}_{\mathrm{si}}, \mathrm{M}^{2}\end{array}$ & $\begin{array}{c}\text { Відстань від шару } \\
\text { арматури до } \\
\text { найбільш стиснутої } \\
\text { грані перерізу } \mathrm{z}_{\mathrm{s}}, \mathrm{м}\end{array}$ \\
\hline 1 & 0.001473 & 0.5525 \\
\hline 2 & 0.001473 & 0.5015 \\
\hline 3 & 0.000226 & 0.035 \\
\hline
\end{tabular}

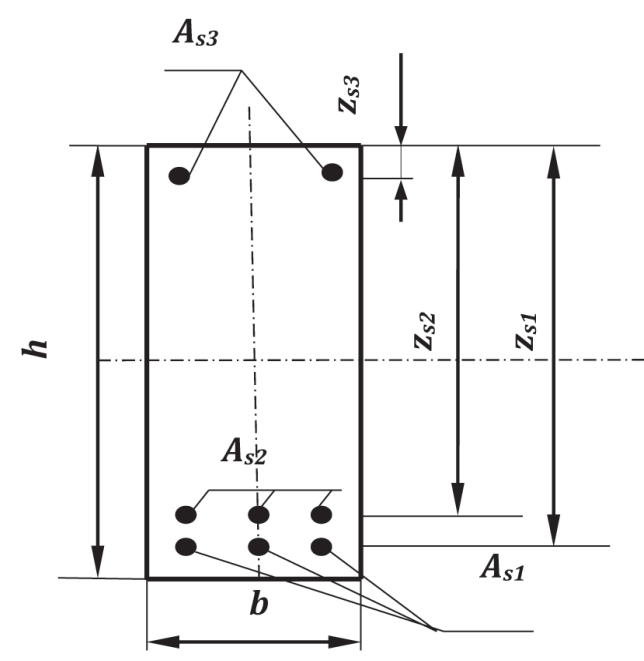

Рис.4. Переріз балки 


\section{WHI 1 Mah}

$-35+25+26=86$ мм, для верхньої

Таблиия 3. Параметри напружено-деформованого арматури - 29 мм.

Виконавши розрахунок за деформаційним методом, отримаємо повну криву стану перерізу до руйнування бетону для уточненого армування розтягнутої зони. В табл. 3 представлено результати підрахунків параметрів напруженодеформованого стану розрахункового перерізу при раціональному армуванні, визначеному підбором.

Напруження в арматурі кожного шару для останніх точок сягають межі текучості -416,6МПа у розтягнутій зоні та 435 МПа у стиснутій. На рис.5 приведена повна крива стану перерізу до руйнування бетону стиснутої зони. Як видно 3 рисунку, крива стану перерізу має низхідну гілку. Згідно з табл. 3, максимум несучої здатності не відповідає граничному стану за деформаціями бетону $\left(\varepsilon_{c(l)}=0.002624<0.00328\right)$ та арматури $\left(\varepsilon_{s l}=-0.002616\right.$, тобто більше за абсолютним значенням $\varepsilon_{s 0}=-0.002083$, але значно менше за $\left.\varepsilon_{u d}=-0.020\right)$.

Оскільки визначена несуча здатність балки $M=$ $516 \mathrm{\kappa H} \cdot \mathrm{м}$ перевищує зовнішній момент $M_{E d}=506 \kappa \mathrm{H} \cdot \mathrm{M}$ всього на 2\%, що менше $5 \%$, це означає, що необхідна точність розрахунку забезпечена. Тому можна вважати, що процес визначення армування закінчений. Для досягнення необхідної точності, як правило, повторюють розрахунки 2-3 рази.

Таким чином, прямим підбором отримали “точне” рішення щодо площі армування перерізу балки, з урахуванням вимог конструювання. Використовуючи дані табл. 1 та вихідні дані, наведені вище, можна отримати, в першому наближенні, необхідну величину раціонального армування за першим підходом по формулі (5):

$$
\begin{gathered}
\varepsilon_{s 0}=\frac{f_{y d}}{E_{s}}=\frac{416.6}{200000}=0.002083, \\
\bar{\aleph}=\frac{\varepsilon_{c u 1}-\varepsilon_{s 0}}{d_{0} \varepsilon_{c 1}}=\frac{0.00328-(-0.002083)}{0.6 \cdot 0.00169}=5.68705,
\end{gathered}
$$$$
x_{1}=\frac{\varepsilon_{c u 1}}{\aleph}=\frac{0.00328}{0.961111}=0.341271,
$$$$
A_{s}=\frac{M-\frac{b f_{c d}}{\aleph^{2}} F_{C M}}{f_{y d}\left(x_{1}-d_{0}\right)}=
$$$$
\begin{gathered}
=\frac{0.506-\frac{0.3 \cdot 17}{32.342538} \cdot 1.629636}{-416.6(0.341271-0.5525)}= \\
=0.002758 \mathrm{M}^{2} .
\end{gathered}
$$

Отримана величина площі арматури може бути

\begin{tabular}{|c|c|c|c|c|c|c|c|c|}
\hline \multirow{2}{*}{ 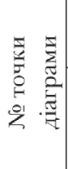 } & \multicolumn{2}{|c|}{$\begin{array}{c}\text { Відносні деформації на } \\
\text { грані бетону }\end{array}$} & \multirow{2}{*}{$\mid \begin{array}{c}\text { Кривизна } \\
\text { вигнутої осі } \\
\text { в перерізі } \\
\text { балки, } \\
\text { к }\end{array}$} & \multirow{2}{*}{$\begin{array}{c}\text { Допоміжна } \\
\text { величина, } \\
\gamma\end{array}$} & \multirow{2}{*}{$\begin{array}{c}\text { Висота } \\
\text { стиснутої } \\
\text { зони } \\
\text { бетону, } \\
x_{1}, \text { м }\end{array}$} & \multirow{2}{*}{$\begin{array}{c}\text { Відносна } \\
\text { кривизна, } \\
\kappa\end{array}$} & \multirow{2}{*}{$\begin{array}{l}\text { Поздовжня } \\
\text { сила } N, \mathrm{MH}\end{array}$} & \multirow{2}{*}{$\begin{array}{c}\text { Згинальний } \\
\text { момент М, } \\
\text { МН·м }\end{array}$} \\
\hline & $\begin{array}{c}\text { стиснутій, } \\
\varepsilon_{(1)}^{(\mathrm{i})}\end{array}$ & $\begin{array}{l}\text { розтягну- } \\
\text { тій, } \varepsilon_{(2)}^{(\mathrm{i})}\end{array}$ & & & & & & \\
\hline 1 & 0.000328 & -0.000557 & 0.001476 & 0.194083 & 0.2222 & 0.87337 & 0.00780 & 0.125168 \\
\hline 2 & 0.000656 & -0.001049 & 0.002843 & 0.388166 & 0.2308 & 1.68205 & 0.00442 & 0.230392 \\
\hline 3 & 0.000984 & -0.001476 & 0.004100 & 0.582249 & 0.2400 & 2.426036 & -0.00169 & 0.317093 \\
\hline 4 & 0.001312 & -0.001836 & 0.005248 & 0.776331 & 0.2500 & 3.10532 & -0.0033 & 0.386677 \\
\hline 5 & 0.00164 & -0.002132 & 0.006287 & 0.970414 & 0.2609 & 3.71992 & 0.00569 & 0.440528 \\
\hline 6 & 0.001968 & -0.002427 & 0.007325 & 1.164497 & 0.2686 & 4.33451 & 0.00044 & 0.482107 \\
\hline 7 & 0.002296 & -0.002755 & 0.008419 & 1.35858 & 0.2727 & 4.98146 & 0.00600 & 0.504028 \\
\hline 8 & 0.002624 & -0.003066 & 0.009485 & 1.552663 & 0.27665 & 5.61223 & 0.00504 & 0.5165814 \\
\hline 9 & 0.002952 & -0.003476 & 0.010715 & 1.746746 & 0.27551 & 6.34004 & 0.00418 & 0.5126546 \\
\hline 10 & 0.00328 & -0.003772 & 0.011753 & 1.940828 & 0.27907 & 6.95463 & 0.00622 & 0.5062520 \\
\hline
\end{tabular}

стану перерізу
Рис.5 Діаграма стану залізобетонної балки при уточненому армуванні

реалізована шістьма стрижнями Ø25, $A_{s}=0.002946 \mathrm{~m}^{2}$ або п'ятьма стрижнями Ø28, $A_{s}=0.003079 \mathrm{M}^{2}$. Прямим розрахунком, виходячи з кратної площі реальних арматурних стрижнів і розташування їх двома шарами, також отримано сумарну площу армування $A_{s}=0,002946$ м $^{2}$ (6Ø25). Тому, можна вважати, що залежність (5) дає достатньо точний результат.

Визначимо раціональне армування за другим підходом (рис. 2). При цьому, як показав аналіз, немає необхідності використовувати граничний деформований стан перерізу. Виконавши розрахунки за залежностями (9) та (10), отримаємо:

$$
\begin{aligned}
& D=4 d_{0}^{2}-\frac{8 M_{E d}}{b f_{c d}}=4 \cdot 0,558^{2}-\frac{8 \cdot 0,506}{0,3 \cdot 17}=0,45173, \\
& x_{1}=\frac{-2 d_{0} \pm \sqrt{D}}{-2 \lambda}=\frac{-2 \cdot 0,5525+\sqrt{0,45173}}{-2 \cdot 0,8}=0,27743 .
\end{aligned}
$$

Другий корінь рішення квадратного рівняння не є дійсним, оскільки його значення перевищує висоту перерізу, що не відповідає другій формі рівноваги.

Використовуючи рівняння (8) для визначення раціонального армування при згині отримуємо: 


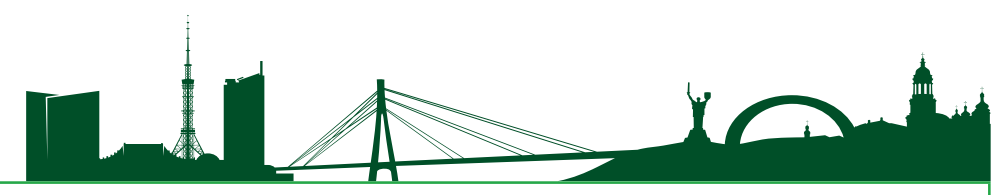

Таблиия 4. Порівняння результатів спрощених підходів для визначення площі розтягнутої арматури.

\begin{tabular}{|c|c|c|c|c|c|c|}
\hline \multirow{2}{*}{$\begin{array}{c}\text { Площа } \\
\text { арматури, } \\
\text { отримана } \\
\text { прямим } \\
\text { підбором, } \\
\text { см² }^{2}\end{array}$} & \multicolumn{2}{|c|}{ Перший підхід } & \multicolumn{2}{|c|}{ Другий підхід } & \multicolumn{2}{|c|}{ Третій підхід } \\
\hline & $\begin{array}{c}\text { площа } \\
\text { арматури, } \\
\text { см² }^{2}\end{array}$ & $\begin{array}{c}\text { відхилення, } \\
\%\end{array}$ & $\begin{array}{c}\text { площа } \\
\text { арматури, } \\
\text { см }^{2}\end{array}$ & $\begin{array}{c}\text { відхилення, } \\
\%\end{array}$ & $\begin{array}{c}\text { площа } \\
\text { арматури, } \\
\text { см}^{2}\end{array}$ & $\begin{array}{c}\text { відхилен- } \\
\text { ня, \% }\end{array}$ \\
\hline 29,46 & 27,58 & 6,8 & 27,17 & 8,4 & 28 & 5,2 \\
\hline
\end{tabular}

$A_{s}=\frac{x_{1} b \lambda f_{c d}}{f_{y d}}=\frac{0,27743 \cdot 0,3 \cdot 0,8 \cdot 17}{416,6}=0,002717 \mathcal{M}^{2}$

Виконавши співставлення 3 результатами визначення площі арматури в наведених вище прикладах, можна констатувати, що і в даному випадку ми отримуємо достатньо точний результат.

Використовуючи третій підхід для визначення раціонального армування при згині, за формулами (12, 13) отримаємо:

$x_{1}=\frac{d_{0} \varepsilon_{c u 1, c d}}{\varepsilon_{c u 1, c d}+\varepsilon_{s 0, d}}=\frac{0.5525 \cdot 0.00328}{(0.00328+0.002083)}=0.338 \mathcal{M}$.

Перевіряємо величину висоти стиснутої зони $x_{1} \leq 0.6 d_{0}$. Висота стиснутої зони приблизно дорівнює $0.6 d_{0}(0,338 \cdot 0,6 \cdot 0,5525=0,332)$. Тому, площу розтягнутої арматури обчислюємо за залежністю (14).

Відповідно, необхідна площа арматури становить:

$A_{s}=\frac{-M}{2 f_{y d}\left(x_{1}-d_{0}\right)}=\frac{-0.506}{2 \cdot 416.6(0.338-0.5525)}=0.0028 \mathrm{~m}^{2}$.

Розрахунки за трьома спрощеними підходами для визначення площі розтягнутої арматури, представлені в табл. 4, показують, що всі три підходи дають практично однаковий результат.

Для розрахунків рекомендовано третій підхід, тим більше, що найпростіші залежності (12) - (15) дозволяють визначити площу армування незалежно від того, яку діаграму деформування бетону використовують. Цей метод розрахунку є найбільш наближеним до результатів, отриманих прямим підбором.

\section{ВИСНОВКИ}

Аналіз системи рівнянь для визначення несучої здатності елементів прямокутного перерізу при згині дозволив заключити, що попередню величину площі армування розтягнутої зони можливо визначити аналітичним шляхом.

Представлений аналіз прямого підбору і трьох підходів до визначення площі арматури прямокутного перерізу з одним шаром армування показав, що всі вони дають практично один і той же результат.

Рекомендовано використовувати найпростіші залежності (12) - (15), які дозволяють визначити площу армування незалежно від того, яку діаграму деформування бетону ми використовуємо. Цей розрахунок дає результати, найбільш наближені до результатів, отри- маних прямим підбором. Вказані залежності дозволяють також визначити значення площі попередньо напруженої арматури.

\section{БІБАІОГРАФІЧНИЙ СПИСОК}

1 Конструкції будинків і споруд. Бетонні та залізобетонні конструкції. Основні положення: ДБН В.2.6-98:2009.-[Чинний від 2011-06-01]. - Київ: ДП "Укрархбудінформ". 2011. - 69 с.- (Державні буд. норми України).

2 Конструкції будинків і споруд. Бетонні та залізобетонні конструкції з важкого бетону. Правила проектування: ДСТУ Б В.2.6-156:2010.-[Чинний від 2011-06-01]. - Київ: ДП "Укрархбудінформ". 2011. - 118 с.- (Національний стандарт України).

3 Andriy Bambura, Oleksandr Gurkivskiy, Marianna Bezbozhna To assessment of bearing capacity and deformability of the reinforced concrete structures on the basis of material deformation real diagrams and deformation approach// Keep Concrete Attractive: Proc. of the fib Symp. - Budapest. - Hungary, 23-25 May 2005. - V.II - P. 742-747.

4 Бамбура А.М. Деформаційна модель та алгоритм визначення напружено-деформованого стану розрахункового перерізу залізобетонних елементів. / А.М. Бамбура, О.Б. Гурківський, М.С. Безбожна, О.В. Дорогова. // Стр-во, материаловедение, машиностроение: Сб. научных тр. Вып. №50. - Днепропетровск., ПГАСА, 2009. C. $19-25$.

\section{REFERENCES}

1 Structures of buildings and facilities. Concrete and reinforced concrete structures. Main provisions. (2011). DBN V.2.6-98:2009 [valid from 2011-06-01]. -Kyiv: SE “Ukrarhbudinform”, 2011.-69 p.- (State Construction Norms) [in Ukrainian].

2 Structures of buildings and facilities. Concrete and reinforced concrete structures of heavyweight concrete. Design rules. (2011). DSTU B V.2.6-156:2010 [valid from 2011-06-01]. - Kyiv: SE “Ukrarhbudinform", 2011.- 118 p. (National Standard of Ukraine) [in Ukrainian].

3 Bambura, A., Gurkivskiy, O., \& Bezbozhna, M. (2005). To assessment of bearing capacity and deformability of the reinforced concrete structures on the basis of material deformation real diagrams and deformation approach // Proc. from Keep Concrete Attractive: The fib Symp. (23-25 May 2005). (pp. 742-747). Budapest [in English].

4 Bambura, A., Gurkivskiy, O., Bezbozhna, M., \& Dorohova, O. (2009). Deformation model and algorithm for the determination of the stress-strain state of the design cross-section of reinforced concrete elements. Construction, materials sciences and engineering industry, 50, p.19-25. Dnepropetrovsk: PSASA [in Ukrainian]. 